\title{
Pengaruh Peta Pikiran Dalam Tatanan Pembelajaran Terhadap Hasil Belajar Siswa
}

\author{
Masni Veronika Situmorang $)^{*}$ \\ ${ }^{1)}$ Universitas HKBP Nommensen Pematangsiantar \\ *masniveronika@gmail.com
}

\begin{abstract}
Abstrak: Penelitian ini bertujuan untuk mengetahui apakah peta pikiran dalam tatanan pembelajaran berpengaruh terhadap hasil belajar siswa. Populasi yang digunakan dalam penelitian ini adalah seluruh siswa kelas XI IPA yang terdiri atas 3 kelas. Sementara sampel penelitian adalah total sampling (sampel total) sebanyak 35 orang untuk kelas STAD dan Peta Pikiran (kelas XI IPA-1), 35 orang untuk kelas STAD (kelas XI IPA-2) dan 35 orang untuk kelas konvensional (XI-IPA 3). Melalui uji persyaratan, hasil belajar siswa memiliki distribusi normal. Melalui pembelajaran STAD+Peta Pikiran diperoleh rata-rata hasil belajar sebesar 81,67; dengan menggunakan STAD diperoleh sebesar 75,37; sedangkan dengan menggunakan Konvensional diperoleh 68,42. Kemudian hasil belajar yang diperoleh dianalisis dengan menggunakan uji-F (analisis varians satu arah) dengan taraf kepercayaan $\propto=0,01$; sehingga diperoleh $\mathrm{F}_{\text {hitung }}>\mathrm{F}_{\text {tabel }}(13,86>4,81)$. Hal ini berarti bahwa $\mathrm{H}_{\mathrm{o}}$ ditolak dan $\mathrm{H}_{\mathrm{a}}$ diterima. Dengan kata lain bahwa penggunakan peta pikiran dalam tatanan pembelajaran memiliki pengaruh yang signifikan terhadap hasil belajar siswa. Berikutnya hasil belajar diuji dengan uji Tukey (Honestly Significant Differences = HSD), dengan tujuan untuk melihat apakah ada perbedaan hasil belajar antara ketiga perlakuan (pembelajaran). Hal ini berarti bahwa model pembelajaran STAD+peta pikiran memperlihatkan hasil belajar yang lebih baik.
\end{abstract}

Kata Kunci: Peta Pikiran, Pembelajaran Kooperatif

\section{Pendahuluan}

Belajar Biologi yaitu belajar mengenai segala sesuatu yang berkaitan dengan makhluk hidup. Hal ini berarti kemampuan biologi membutuhkan pemahaman dan pengetahuan yang luas. Kegiatan pembelajaran yang selama ini dilaksanakan di sekolah tersebut kebanyakan masih dalam bentuk pembelajaran yang berpusat pada guru bukan pada siswa (Asriyadin \& Fatkhulloh, 2012). Kegiatan pembelajaran yang seperti ini tidaklah dapat menata cara berpikir siswa. Siswa menjadi pasif, sulit untuk mengutarakan pendapat, dan sulit untuk mengambil keputusan secara bertanggung jawab. Dengan kata lain hasil belajar dan kreativitas siswa tidak berkembang secara optimal.

Ketika siswa membuat catatan, seringkali langsung memindahkan seluruh informasi ke buku atau catatannya. Bentuk pencatatatan seperti ini menyebabkan siswa kesulitan dalam mengingat kembali dan menggunakan informasi untuk belajar dan bekerja. Berikutnya ketika ingin menyajikan informasi, dibutuhkan waktu yang lebih lama. Hal ini menyebabkan lemahnya ingatan akan materi yang telah disampaikan. Bentuk pencatatan yang dapat mengatasi masalah ini adalah dengan Peta Pikiran. Teknik pencatatan yang seperti ini tidak hanya dapat membantu dalam mempelajari informasi yang diberikan, tapi juga dapat merefleksikan pemahaman personal yang mendalam atas informasi tersebut. Selain itu Peta Pikiran juga dapat memperkuat penguasaan konseptual dan memberikan tanggapan menyenangkan terhadap objek-objek (Buzan, 2014).

Berdasarkan hasil penelitian yang dilakukan oleh (Muldayanti, 2013) bahwa diperoleh 81,57 untuk ratarata dari hasil belajar sementara untuk kreativitas siswa mencapai 83,38 yang termasuk kategori baik. Selain itu pada materi pokok Fluida Dinamis menunjukkan peningkatan yang signifikan hasil belajar siswa setelah dilakukan pembelajaran dengan peta pikiran. Hal ini dapat dilihat dari persentase rata-rata perolehan nilai pada saat pretest sebesar $37 \%$ menjadi $64,85 \%$ pada saat post test I dan meningkat menjadi $85,42 \%$ pada saat post test II atau mengalami peningkatan rata-rata persentase perolehan nilai sebesar 48,42\% (Siagian \& Tampubolon, 2015). 
Dengan demikian untuk meningkatkan rata-rata nilai siswa dan keaktifan siswa dalam proses belajar maka perlu diadakan perubahan-perubahan dalam perencanaan pembelajaran sehingga siswa merasa tertarik untuk belajar, bukan merasa bosan dan menjenuhkan. Dalam penelitian ini digunakan peta pikiran yang dikombinasikan dengan pembelajaran kooperatif tipe Student Team Achiecement Davision (STAD). Hal ini sesuai dengan hasil penelitian yang untuk pembelajaran dengan model kooperatif tipe STAD ini diperoleh nilai sebesar 77,63, yang diperoleh berdasarkan karakteristik peserta didik (Andaningsih \& Wilujeng, 2015). Adapun tujuan penelitian ini dilakukan adalah untuk mengetahui apakah peta pikiran dalam tatanan pembelajaran berpengaruh terhadap hasil belajar siswa.

\section{Metode}

Penelitian yang dilakukan adalah penelitian quasi eksperimen. Penelitian ini menggunakan tiga kelompok sampel yang diteliti yaitu satu kelompok kontrol dan dua kelompok eksperimen. Data yang digunakan dalam penelitian ini berupa tes hasil belajar. Sebelumnya data yang diperoleh dilakukan uji persyaratan yang terdiri dari uji normalitas data menggunakan Uji Liliefors dan uji homogenitas data menggunakan Uji Bartlett. Uji normalitas yang dilakukan dengan asumsi bahwa data hasil belajar bersifat normalsedangkan uji homogenitas dilakukan dengan asumsi bahwa data hasil belajar bersifat homogen. Selanjutnya, untuk pengujian hipotesis dilakukan dengan menggunakan teknik analisis varians satu arah. Berikutnya, untuk mengetahui perlakuan mana yang lebih baik maka akan dilakukan uji perbedaan rata - rata hasil belajar dengan menggunakan Uji Tukey.

\section{Hasil dan Pembahasan}

Dari hasil pre test diketahui nilai rata-rata siswa pada kelas STAD+Peta Pikiran sebesar 49,07 dengan simpangan baku (SD) sebesar 6,97; kelas STAD sebesar 47,78 dengan simpangan baku (SD) sebesar 7,89; dan kelas konvensional 47,84 dengan simpangan baku (SD) sebesar 7,78. Hasil uji statistik menunjukkan bahwa nilai rata-rata hasil belajar siswa pada ketiga kelas relatif sama. Dengan demikian dapat ditarik kesimpulan bahwa tidak ada perbedaan nilai siswa pada ketiga kelas sebelum diberikan perlakuan dengan menggunakan pembelajaran yang berbeda. Untuk lebih jelasnya disajikan dalam tabel berikut.

Tabel 1. Perbandingan Nilai Pre Test Siswa pada Kelas Peta Pikiran+STAD, Kelas STAD, dan Kelas Konvensional

\begin{tabular}{cccc}
\hline Parameter Hasil & \multicolumn{3}{c}{ Nilai Pre Test pada Model Pembelajaran } \\
\hline & STAD & STAD+Peta Pikiran & Konvensional \\
Rata-Rata & 47,78 & 49,07 & 47,84 \\
Standar Deviasi (SD) & 7,89 & 6,97 & 7,78 \\
Range & 30 & 26,67 & 30 \\
\hline
\end{tabular}

Selanjutnya berdasarkan hasil post test diketahui nilai rata-rata siswa pada kelas STAD+Peta Pikiran sebesar 81,67 dengan simpangan baku (SD) sebesar 10,28; kelas STAD sebesar 75,37 dengan simpangan baku (SD) sebesar 11,50 dan kelas konvensional 68,42 dengan simpangan baku (SD) sebesar 10,19. Hasil uji statistik menunjukkan bahwa setelah diberikan perlakuan pembelajaran yang berbeda diperoleh nilai siswa dengan menggunakan pembelajaran dengan Peta Pikiran yang dikombinasikan dengan kooperatif STAD relatif lebih tinggi bila dibandingkan dengan hasil belajar siswa baik pada kelas kooperatif STAD maupun pada kelas Konvensional. Penjelasan dari kesimpulan tersebut akan lebih jelas dengan melihat tabel berikut.

Tabel 2. Perbandingan Nilai Post Test Siswa pada Kelas Peta Pikiran+STAD, Kelas STAD, dan Kelas Konvensional

\begin{tabular}{cccc}
\hline Parameter Hasil & \multicolumn{3}{c}{ Nilai Post Test pada Model Pembelajaran } \\
\hline & STAD & STAD+Peta Pikiran & Konvensional \\
Rata-Rata & 75,37 & 81,67 & 68,42 \\
Standar Deviasi (SD) & 11,50 & 10,28 & 10,19 \\
Range & 50 & 43,34 & 43,33 \\
\hline
\end{tabular}


Berikutnya dilakukan pengujian hipotesis yang menggunakan uji-F atau analisis varians satu arah. Uji-F dilakukan dengan membandingkan nilai rata-rata pre test dan post test dari ketiga kelas penelitian.

Melalui perhitungan, diperoleh harga $F_{\text {hit }}=0,34$. Sedangkan harga $F_{\text {tab }}$ dengan $d k(2,105)$ untuk $\propto(0,05)$ $=3,08$. Berdasarkan pengujian $\mathrm{H}_{\mathrm{o}}$ diterima jika $\mathrm{F}_{\text {hit }}<\mathrm{F}_{\text {tab }}$ dan $\mathrm{H}_{\mathrm{o}}$ ditolak jika sebaliknya. Maka berdasarkan hasil pengujian hipotesis diketahui bahwa $\mathrm{F}_{\text {hit }}<\mathrm{F}_{\text {tab }}(0,34<3,08)$, sehingga $\mathrm{H}_{\mathrm{o}}$ diterima dan $\mathrm{H}_{\mathrm{a}}$ ditolak. Jadi dapat disimpulkan bahwa : tidak ada perbedaan hasil belajar siswa pada saat dilakukan pre test. Untuk lebih jelasnya akan disajikan pada tabel berikut.

Tabel 3. ANAVA untuk Pre Test

\begin{tabular}{cccccc}
\hline Sumber Varians & $\mathrm{dK}$ & $\mathrm{JK}$ & $\mathrm{KT}$ & Fhit & Ftab $(\propto=0,05)$ \\
\hline Rata-Rata & 1 & 251221,39 & 251221,39 & & \\
Antar Kelompok & 2 & 38,60 & 19,30 & & \\
Dalam Kelompok & 105 & 5999,66 & 57,14 & 0,34 & 3,08 \\
Total & & 257259,65 & & & \\
\hline
\end{tabular}

Sementara itu untuk post test, diketahui harga $\mathrm{F}_{\text {hit }}=13,86$. Sedangkan harga $\mathrm{F}_{\text {tab }}$ dengan $\mathrm{dk}(2,105)$ untuk $\propto(0,01)=4,81$. Berdasarkan pengujian $H_{o}$ diterima jika $F_{\text {hit }}<F_{\text {tab }}$ dan $H_{o}$ ditolak jika sebaliknya. Maka berdasarkan hasil pengujian hipotesis diketahui bahwa $F_{\text {hit }}>F_{\text {tab }}(13,86>4,81)$. Hal ini berarti $H_{o}$ ditolak dan $\mathrm{H}_{\mathrm{a}}$ diterima. Berdasarkan hal tersebut dapat ditarik kesimpulan bahwa pada saat post test: Peta pikiran dalam tatanan pembelajaran berpengaruh yang signifikan terhadap hasil belajar siswa. Uji statistiknya tercantum pada tabel berikut ini.

Tabel 4. ANAVA untuk Post Test

\begin{tabular}{cccccc}
\hline Sumber Varians & $\mathrm{dK}$ & $\mathrm{JK}$ & $\mathrm{KT}$ & Fhit & Ftab $(\propto=0,05)$ \\
\hline Rata-Rata & 1 & 610001,57 & 610001,57 & & \\
Antar Kelompok & 2 & 3158,67 & 1579,33 & & \\
Dalam Kelompok & 105 & 11960,53 & 113,91 & 13,86 & 4,81 \\
Total & & 625120,77 & & & \\
\hline
\end{tabular}

Selanjutnya, untuk mengetahui perlakuan mana yang lebih baik dilakukan uji lanjut dengan menggunakan Uji Tukey (sering disebut Honestly Significant Differences = HSD) yang dilakukan dengan melakukan pengujian terhadap hasil belajar siswa. Hasil uji beda rata-rata tersebut tercantum pada tabel berikut ini.

Tabel 5. Uji Tukey dari Hasil Belajar

\begin{tabular}{lccc}
\hline \multicolumn{1}{c}{ Pasangan Perlakuan } & $\begin{array}{c}\text { Harga Mutlak } \\
\text { Selisih }\end{array}$ & $\begin{array}{c}\text { Nilai } \\
\mathrm{T}(\alpha=0,05)\end{array}$ & $\begin{array}{c}\text { Nilai } \\
\mathrm{T}(\alpha=0,01)\end{array}$ \\
\hline $\begin{array}{l}\text { STAD + Peta Pikiran dan STAD } \\
(81,67)(75,37)\end{array}$ & $6,30^{* *}$ & 5,82 & 7,30 \\
$\begin{array}{l}\text { STAD + Peta Pikiran dan Konvensional } \\
(81,67)(68,42)\end{array}$ & $13,25^{* *}$ & 5,82 & 7,30 \\
$\begin{array}{l}\text { STAD dan Konvensional } \\
(75,37)(68,42)\end{array}$ & $6,95^{* *}$ & 5,82 & 7,30 \\
\hline
\end{tabular}

Keterangan : tanda ${ }^{* *}$ menunjukkan adanya perbedaan yang sangat signifikan.

Berdasarkan uji Tukey yang telah dikemukakan menunjukkan terdapat perbedaan yang sangat signifikan antara perlakuan STAD yang diperkaya dengan Peta Pikiran dengan STAD. Terdapat juga perbedaan yang sangat signifikan antara perlakuan STAD yang diperkaya dengan Peta Pikiran dengan Konvensional. Demikian juga halnya ada perbedaan yang sangat signifikan antara perlakuan STAD dengan Konvensional. Dalam hal ini berdasarkan rata-rata hasil belajarnya, pembelajaran dengan model kooperatif tipe STAD yang diperkaya dengan peta pikiran jauh lebih baik. 
Penggunaan model pembelajaran merupakan salah satu indikator penting yang menentukan hasil belajar siswa. Model pembelajaran dapat divariasikan sebagai alat bukan hanya meningkatkan hasil belajar siswa, namun pula meningkatkan kemampuan psikomotorik dan keaktifan siswa (Djamarah, et. al., 2013).

Pada penelitian ini menghasilkan rata-rata nilai yang lebih baik pada kooperatif tipe STAD yang diperkaya dengan peta pikiran. Hal ini terjadi karena teknik pencatatan peta pikiran pada dasarnya menekankan pada pengoptimalisasian kerja otak dalam memetakan materi pelajaran dari konsep yang paling utama sampai pada konsep yang paling sederhana (Buzan, 2014). Selanjutnya dijelaskan juga bahwa teknik peta pikiran akan memotivasi siswa untuk berusaha meningkatkan kreativitas belajar melalui teknik peta pikiran yang mengandung banyak warna, gambar, dan motif-motif. Siswa akan lebih diarahkan ketika menerima informasi dari guru, kemudian menyimpan informasi tersebut, dan memampukan diri mereka untuk mengingat kembali materi pelajaran dalam jangka waktu yang lebih lama. Dengan menggunakan peta pikiran pulalah siswa dapat menganalisis informasi lebih cepat dan menghubungkan antara materi yang satu dengan materi yang berikutnya akan mereka terima dari guru. Hasil penelitian ini juga menunjukkan hal yang demikian. Dapat dilihat siswa mampu membuat gagasan utama, dimana gagasan utama yang merupakan kunci utama dalam pembuatan peta pikiran, telah menggunakan huruf kapital dan diletakkan/ditulis di tengah kertas. Kemudian dari gagasan utama siswa juga dapat menyederhanakan ke bentuk yang lebih sederhana yaitu dalam bentuk penarikan cabang tingkat kedua, ketiga, dan seterusnya.

Dalam hubungannya dengan nilai yang diperoleh, siswa sudah mampu untuk mensintesis. Soal-soal yang diberikan dapat dijawab karena didukung oleh peta pikiran. hal tersebut terlihat ketika siswa menggambar cabang, dimana mereka telah mampu mengkreasi dengan menambahkan warna-warna, gambar, dan simbolsimbol yang tentunya akan menambah kesan yang lebih menarik bagi siswa. Sebagai hasil akhirnya, siswa memiliki skill untuk mengingat kembali bahkan mampu menyampaikan kembali informasi yag telah diperoleh sebelumnya secara cepat dan tepat.

Dari pengamatan peneliti selama melakukan penelitian, tampak bahwa siswa sangat antusias dalam menerima pelajaran dengan menggunakan kooperatif STAD yang kemudian dikombinasikan dengan peta pikiran yang dibuat oleh siswa selama melakukan pembelajaran. Dalam pembelajaran kooperatif, siswa yang diminta untuk bekerja secara berkelompok tampak bersemangat dalam hal berdiskusi maupun dalam melakukan tanya jawab selama proses pembelajaran. Sementara siswa pada kelas kooperatif STAD hanya terpacu pada diskusi kelompok yang dilakukan. Siswa hanya mampu berkelompok dalam membahas materi dan terlibat dalam aktivitas tanya jawab saja. Berbeda dengan kedua kelas sebelumnya, kelas konvensional hanya mengandalkan guru sebagai pusat informasi, dimana siswa menjadi kurang termotivasi dalam belajar. Terjadinya hasil belajar yang lebih baik pada model kooperatif tipe STAD yang diperkaya dengan peta pikiran karena pada pembuatan peta pikiran siswa dipacu untuk memetakan materi yang telah dipelajari dan kreatifitas serta kemampuan psikomotorik siswa dapat meningkat. Demikian juga halnya dengan kemampuan kognitif siswa.

Dengan melihat hasil yang telah diteliti dan dibahas, maka ditarik kesimpulan bahwa penggunaan kooperatif STAD yang dikombinasikan dengan peta pikiran dalam mekanisme pelaksanaannya lebih efektif digunakan dan dapat meningkatkan kreativitas belajar siswa dan pengelolaan kegiatan belajar mengajar bila dibandingkan dengan pembelajaran yang menggunakan kooperatif STAD maupun dengan menggunakan pembelajaran konvensional.

\section{Simpulan}

Melalui hasil penelitian yang telah dibahas di atas, maka dapat ditarik kesimpulan bahwa: Terdapat perbedaan yang sangat signifikan rata-rata nilai hasil belajar siswa yang diajar dengan menggunakan STAD+Peta Pikiran dengan model kooperatif tipe STAD dan Konvensional.

\section{Ucapan Terima Kasih}

Terima kasih kepada bapak/ibu guru SMA Swasta Methodist Pematang Siantar, yang telah banyak membantu proses penelitian ini dari awal hingga akhirnya selesai terkhusus Ibu Dunella Purba, S.Pd. sebagai guru Biologi di SMA Swasta Methodist Pematangsiantar. 


\section{Daftar Pustaka}

Aini, Z. Ramdani, A., Raksun, A. (2018). Perbedaan Penguasaan Konsep Biologi Dan Kemampuan Berpikir Kritis Siswa Kelas X Pada Penerapan Model Pembelajaran Kooperatif Tipe Group Investigation Dan Guided Inquiry di MAN 1 Praya. Jurnal Pijar MIPA, 13(1), 19-23. http://dx.doi.org/10.29303/jpm.v13i1.466.

Andaningsih, W., Wilujeng, S. (2015). Studi Komparasi Hasil Belajar Biologi Menggunakan Model Pembelajaran Kooperatif Antara Tipe STAD Dan TGT Berdasarkan Karakeristik Peserta Didik Di SMA Negeri 1 Sentani. Jurnal Ilmu Pendidikan Indonesia. 3(2). 50-62. https://doi.org/10.31957/jipi.v3i2.356.

Asriyadin, A., \& Fatkhulloh, F. (2012). Pengaruh Moving Class dan Belajar di Pagi Hari terhadap Hasil Belajar Fisika. In Seminar Nasional Fisika dan Pendidikan Fisika Ke-2 2012. Sebelas Maret University.

Balim. A. G. (2013). The Effect Of Mind-Mapping Applications On Upper Primary Students' Success And Inquiry-Learning Skills In Science And Environment Education. Journal International Research in Geographical and Environmental Education, 22(4), 337-352. https://doi.org/10.1080/10382046.2013.826543.

Buzan, Tony. (2014). Mind Map Untuk Meningkatkan Kreativitas. Jakarta: Gramedia Pustaka Utama.

Darusman, R. (2014). Penerapan Metode Mind Mapping (Peta Pikiran) Untuk Meningkatkan Kemampuan Berpikir Kreatif Matematik Siswa SMP. Infinity Journal, 3(2), 164-173. http://doi.org/10.22460/infinity.v3i2.61.

Djamarah, Syaiful B., Aswan, Zain. (2013). Strategi Belajar Mengajar. Jakarta: Penerbit Rineka Cipta.

Harahap, N. (2013). Penerapan Model Pembelajaran Kooperatif Tipe Stad Terhadap Hasil Belajar Kognitif, Motivasi, Dan Aktivitas Belajar Siswa Pada Konsep Ekosistem Di MTSN Model Banda Aceh. Visipena, 4(2), 57-76. https://doi.org/10.46244/visipena.v4i2.212

Harjanti, D. T. (2014). Penerapan Teknik Peta Pikiran (Mind Map) Untuk Meningkatkan Pemahaman Konsep Geografi Pada Peserta Didik Kelas XI-2 IPS SMAN 1 Rasau Jaya Kabupaten Kubu Raya. Jurnal Geografi GEA, 14(2). 92-98. http://doi.org/10.17509/gea.v14i2.3399.

Herrmann, K. J. (2013). The impact of cooperative learning on student engagement: Results from an intervention. Active Learning In Higher Education, 14(3), 175-187. https://doi.org/10.1177/1469787413498035

Muldayanti, N. D. (2013). Pembelajaran Biologi Model STAD Dan TGT Ditinjau Dari Keingintahuan Dan Minat Belajar Siswa. JPII, 2(1).12-17. https://doi.org/10.15294/jpii.v2i1.2504.

Rahmi, F., Harahap, M. B. (2013). Pengaruh Model Pembelajaran Pencapaian Konsep Dengan Menggunakan Peta Pikiran Sebagai Upaya Mengurangi Miskonsepsi Siswa. Jurnal Inpafi, 1(2). 184-191. https://doi.org/10.24114/inpafi.v1i2.2013.

Rati, W. (2013). Pengaruh Model Pembelajaran Kuantum Bermuatan Peta Pikiran dan Gaya Kognitif terhadap Hasil Belajar 46(1). 55-65. http://dx.doi.org/10.23887/jppundiksha.v46i1.1692.

Slameto. (2010). Belajar dan Faktor - Faktor yang Mempengaruhinya. Jakarta: Penerbit Rineka Cipta.

Siagian, R. M. E., Tampubolon, T. (2015). Pengaruh Teknik Pembelajaran Peta Pikiran (Mind Map) Berbasis Problem Solving Terhadap Hasil Belajar Siswa Pada Materi Pokok Fluida Dinamis Di Kelas XI Semester II SMA Negeri 11 Medan T.P 2014/2015. Inpafi, 3(4). 141-147. http://doi.org/10.24114/inpafi.v3i4.5400.

Sudjana. (2010). Metode Statistik. Bandung: Tarsito.

Sukardi, A.D., Susilo, H., Zubaidah, S. (2015). Pengaruh pembelajaran reciprocal teaching berbantuan peta pikiran (mind map) terhadap kemampuan metakognitif dan hasil belajar siswa SMA. Jurnal Pendidikan Sains: Graduate School of Universitas Negeri Malang. 3(2), 81-89. https://dx.doi.org/10.17977/jps. 